\begin{tabular}{l|l|l|l|l}
\hline Volume 2 & Issue 2 & August (2021) & DOI: 10.47540/ijsei.v2i2.210 & Page: $119-128$ \\
\hline
\end{tabular}

\title{
The Paradox of Peasants Resistance in Wonogoro Malang South, East Java
}

\section{Indonesia}

\author{
Angga Prasetyo Adi ${ }^{1}$, Endriatmo Soetarto ${ }^{2}$, Martua Sihaloho ${ }^{3}$ \\ ${ }^{1,2,3}$ Department of Rural Sociology, Institut Pertanian Bogor, Indonesia \\ Corresponding Author: Angga Prasetyo Adi; Email: anggasatrodarsono@gmail.com
}

A R T I C L E I N F O
Keywords: Agrarian Question;
Dynamic;

INTRODUCTION

Peasant resistance is a form of injustice or deprivation of the current system. The resistance of peasants is inseparable from land disputes (Kodir, Adi 2018). In 2016, there were at least 127 cases in East Java, so that the productivity of agricultural land each year has decreased by an area of 1000 to 1100 hectares (Walhi 2018). Threats to land that occur in rural communities either through military force or with the power of knowledge through policies such as social forestry as control over peasants (Bryant 2008). Land tenure in rural areas controlled by the state or the private sector will create rural areas because rural communities in East Java are peasants who live in subsistence coupled with the status of land ownership which is still unclear.

The resistance of peasants in the Wonogoro area in the process of opposing the existence of social forestry that occurred since 2017. The resistance of peasants against the state regarding land access rights that still overlap not only occurred during the existence of social forestry but long before that resistance has occurred.

The resistance carried out by peasants in 1998 was individual and not organized with other peasants. The resistance carried out by peasants in the Wonogoro area at the beginning of land clearing is a form of the inability of rural communities to access food or landless peasants who do not own land and have to deal with a food crisis. The financial crisis that hit Indonesia in 1998 forced people especially close to the Wonogoro area to open land belonging to Perhutani for use as agricultural land to fulfill their subsistence needs.

Peasants' resistance changed when the mobilization of resistance to social forestry was carried out by peasants actors who had a strong influence on the resistance movement of peasants in the Wonogoro area (Habibi 2021). The mobilization carried out by peasants actors in the process of securing land is wrapped up by actors/capital 
farmers, most of whom have large enough land. The rejection made by actors in the resistance of peasants is not only in the planting and profitsharing systems that exist in social forestry but the existence of land security motives that will reduce the amount of agricultural production which will decrease with land reduction.

The mobilization carried out by actors in the peasants' resistance shows the existence of class differentiation that appears in the social relations in the process of agricultural production (Prause, Le Billon 2020). Agricultural production that occurs cannot be separated from the resources owned by capital farmers who mobilize peasants to reject social forestry. Agricultural resources owned by peasants resistance actors/capital farmers can change the proletarian farmer's desire to accept social forestry. The control of agricultural resources is the key to the mobilization of proletarian farmers who materially also require land redistribution in the social forestry scheme. Safeguarding land for capital farmers who are also actors of peasants resistance has made the basis for the strength of peasants resistance in the Wonogoro area. The veil of peasants resistance is very important to see that safeguarding the land of capital farmers in the Wonogoro area forms a false resistance that only benefits a handful of rural peasants elites who live by exploiting proletarian farmers in the process of agricultural production and class relations.

This research uses a class dynamics theoretical approach built by Marx (1859) building on primitive accumulation which extends the emergence of classes in the social relations process of capital production. Berstein (2010) explains that there are 4 characteristics of social relations in capitalist production. First, the production of commodities is systematic and widespread. Goods produced are not for subsistence needs but as a commodity for market needs to get excess profit from financing production. Second, production capital is invested in the means of production (land, equipment, and machinery) and labor to operate the means of production. The process of managing the means of production and labor creates new commodities which create new value in the process of creating profits.

According to Marx (1856), capitalism is the only way of production (especially land) that is widely available for commodity needs. Third, the accumulation process requires labor as a commodity. The capitalist mode of production depends on social relations between the capitalists as owners of production and workers who exchange their labor for the means of reproduction. Here, labor becomes the only commodity whose use in production creates a value greater than the value of labor. Fourth, the processes that occurred in precapitalist society became a transition to capitalism. The social conditions of capitalist production, exploitation, and accumulation were initially created as they existed in pre-capitalist societies. Dynamics and non-market relations or extraeconomic coercion have the characteristics of economic strength in the form of market-driven coercion (Berstain 2010: 35-38).

Capital accumulation prepares the application of the social relations of capital production with the characteristics of commodity production, capital accumulation, and labor commodities. The process of creating a social class, Berstein (2010) can be identified by four questions: Who owns what? Who did what? Who got what? What are the results they got used for?

The first question relates to social relations in various property regimes, how the means of production are distributed. The ideas and practices of private property and private property are found in a capitalist context and help to explain capitalism itself. This problem is closely related to land, the basis of farming. The spread of commodification of land to become private property or to become a commodity is one of the characteristics of capitalism. The second question concerns the social division of labor. Parties that carry out social production and reproduction activities have been structured as social relations. The third question, regarding the social division of labor or, is often referred to as the distribution of income. Ownership and property or property do not only refer to income as earned by capitalists. Pra-capitalist societies have yields that do not materialize money as a result of production. Such as food produced by small farmers for their consumption or domestic work and other unpaid labor. The fourth question concerns social relations in consumption, reproduction, and accumulation. Such as consumption costs, replacement costs, ceremonial activity costs, and rent. 
The resistance of peasants in the Wonogoro area shows that there is class differentiation that occurs in social relations both in agricultural production and in peasants' resistance. Class differentiation occurs between capital farmers with land ownership of more than 2 hectares and proletarian farmers who have less than 1 hectare of land, which rationally they want land redistribution. Peasants resistance, most of the actors who reject social forestry are capital farmers who own more than 2 hectares of land and use social relations as a means of mobilizing proletarian farmers to reject social forestry.

The resistance of the peasants in the Wonogoro area occurs because of class differentiation between capital farmers and proletarian farmers who need land redistribution but capital farmers make peasant resistance a paradox, covertly as a strategy to secure the land of capital farmers. The dilemma of proletarian farmers is experienced because of a patronage relationship that makes them trapped in a situation of obeying the wishes of their patron or participating in a social forestry program by obtaining land redistribution in a social forestry scheme. The resistance carried out by farmers in the Wonogoro area is due to the relationship of state power through social forestry which forms class dynamics in the resistance of Wonogoro farmers. The patronage system that occurs in peasant resistance cannot be separated from the power relations that operate in production relations.

\section{Materials AND MethodS}

This study uses a critical paradigm (Denzin 1978). which is used in research to see the class dynamics in the resistance of Wonogoro peasants. This research uses qualitative methods to see the class dynamics that occur in the resistance of peasants. The research location was conducted in the Wonogoro area, Gedangan sub-district, Malang regency East Java Province, Indonesia. Determination of informants using purposive and using key informants can lead researchers to be able to meet the next informant. This research uses indepth interviews conducted by 20 informants consisting of capital farmers and proletarian farmers who oppose social forestry. Research data analysis uses descriptive analysis where the data obtained is compiled and interpreted so that it provides information on the actual problem based on the data that has been collected.

\section{RESULTS AND DISCUSSION \\ Mystification of the resistance of Wonogoro peasants}

Peasants' resistance is very important for peasants who live in the confines of state and private regimes. The resistance of peasants in the Wonogoro area has experienced dynamics since the beginning of land clearing in the Wonogoro area. The resistance at the beginning of land clearing in 1998 was very typical of landless people and a lack of land for subsistence needs. The planted by peasants in the Wonogoro area are stapled food crops such as corn and rice with a rainfed irrigation system. In 1998, farmers were not familiar with the banana commodity that was growing as it is today. The banana commodity has not yet developed, so the genealogy of peasants resistance that was carried out by peasants during the first land clearing in 1998 shows that the resistance carried out by peasants is very subsistence.

Peasants' resistance transformed in 2004 with Perhutani's violence against peasants and intimidation that was continuously felt by peasants, creating a sense of collective awareness. The collective awareness felt among peasants to fight Perhutani by analogizing Perhutani with the term "Londo Blangkonan", the term likening Perhutani to the Dutch colonialists. The term used by peasants shows resentment with the Perhutani's actions that blackmail and oppress the peasants. In 2004, regional actors began to emerge with political ideas and views in the peasant movement process. The resistance of peasants has transformed in several phases, initial resistance to meet the needs of a large amount of privatization that occurred in the Wonogoro area, causing peasants resistance to turning into a tool for land security.

The transformation of peasants' resistance with some of the most influential factors is that NGOs enter to provide advocacy to peasants who continue to be haunted by Perhutani for land control carried out by peasants in the Wonogoro area. Peasants actors who are in the peasants can influence peasants who do not own land. In 2006 the resistance actors in the Wonogoro area did not go their way by organizing local-based resistance despite the constant intimidation of peasants at the 
grassroots. Political education owned by the actors is inseparable from NGOs entering the Wonogoro area, where initially some NGOs advocated in Bantur and Pagak sub-districts for land conflicts with the Indonesian Navy. Seeing the land conflict that occurred in the Wonogoro area between peasants and Perhutani, the NGO entered in 2006 and changed the pattern of resistance of peasants in the Wonogoro area.

NGOs entered the Wonogoro area with various considerations and were deemed by the vision and mission of the NGO, as stated by an informant of PT. "Actually, at first he was not in Wonogoro. Organizing friends who conflict with the marines, there are 3 sub-districts, Pagak Bantur and Gedangan sub-districts, now because in a conflict with the marines, these peasants feel pessimistic that there are those who then do not get access to land which is limited, because so far, access The land claimed by the marines, he positioned his claim, right with some cooperation with some of the village's rice farmers for the land to remain concentrated there, why is the concentration option is sugarcane, there are some peasants who then feel hopeless and the majority of plants there want they don't want to have to work other farmers, that's how they started to enter the forest area. That's why as an organization, our friends, how come we can enter the forest area, yes, the period is around 2006. Some of them enter the Wonogoro forest area" (PT, 2020).

Most of the proletarian farmers in the Wonogoro area think that actors and NGOs who are in the ranks of the peasant's resistance are the peasant's saviors from Perhutani's occupation. NGOs and actors cooperate in the process of fighting against Perhutani. NGOs often hold regular meetings with peasants, with a pattern through the power of knowledge relationship with capital farmers. Most capital farmers unconsciously feel hegemony with the actions taken by actors and NGOs. The inclusion of NGOs in the Wonogoro area made peasants resistance to be very dependent on NGOs as intellectual actors. In 2018 the entry of social forestry really showed peasants' resistance as only a safety tool for actors who owned more than 2 hectares of land.

The peasant's resistance movement was carried out by most of the actors who have motives both politically and economically. Peasants' resistance is inseparable from the selective intensiveness that will be obtained in the short and long term in the peasant resistance movement and the patterns of land security carried out by farmer actors. The operation of power relations that form peasants' resistance in the Wonogoro area as land security by mobilizing proletarian peasants. The cornering of proletarian peasants in the pattern of farmer mobilization against peasants resistance is inseparable from the existence of a patronage system that is intertwined in social relations that exist in agricultural production in the Wonogoro area.

The mobilization carried out by actors in the peasant's resistance shows the existence of class differentiation that appears in the social relations of capital farmers with proletariat farmers in the process of agricultural production. Agricultural production that occurs cannot be separated from the resources owned by capital farmers who mobilize proletariat farmers to reject social forestry. Agricultural resources owned by peasant resistance actors can change the peasant's desire to accept social forestry. The control of agricultural resources is the key to the mobilization of peasants who materially also require land redistribution in the social forestry scheme. Safeguarding land for capital farmers who are also actors of peasants resistance has made the basis for the strength of peasants resistance in the Wonogoro area. The veil of peasant resistance is very important to see that safeguarding the land of capital farmers in the Wonogoro area forms a false resistance that only benefits a handful of rural peasant elites who live by exploiting peasants in the process of agricultural production and class relations.

\section{Class disparity in the Wonogoro agricultural production process}

Capital farmers in the Wonogoro area view that land has become a commodity that has a large enough value, and the price of 1 hectare of land can reach 50 million. The commodification of land with high land prices cannot be separated from the relatively high capital accumulation in the Wonogoro area. Capital farmers own large enough land, not from farmers who participate in clearing the land. Control of the land is mostly capital farmers from outside the area, so the land in the Wonogoro area is not only used to meet subsistence needs but has become capital accumulation. There 
is a form of buying and selling carried out by capital farmers in the Wonogoro area, so the privatization of hardened land is going on even though based on mutual trust "Ijol Bontot".

"Ijol bonthot" is a term used by capital farmers on the grounds that farmers do not sell forest land but only compensation for land management that has been cleared. The shift in meaning inland control of the Wonogoro peasants has become the basis for resistance carried out by the peasants, so the land is no longer a means of production to meet subsistence needs. The term "ijol bontot" is compensation for food peasants used by capital farmers in the Wonogoro area for the first time clearing land but the term is a figurative term used by capital farmers in the Wonogoro area to buy and sell land.

The land privatization carried out by capital farmers in the Wonogoro area, the land changed its function from subsistence needs but turned into commodities. Changing the function of land has also substantially changed the patterns and motives of the resistance carried out by capital farmers in opposing social forestry. Peasants' resistance was initially a form of resistance from peasants to Perhutani for extortion and violence. The resistance carried out by farmers has changed substantially with the existence of intensifying selection that will be obtained by actors who are capital farmers who own more than 2 hectares of land. Capital farmers with a land area of more than 2 hectares with a patronage system that runs in rural communities become social capital for capital farmers to attract peasants to participate in peasants' resistance to reject social forestry.

The patronage system that runs in peasants' resistance in the Wonogoro area indicates that there is a differentiation of the class social that occurs not only in the production system. The peasant's resistance which in substance is to change the form of state domination in social forestry, but becomes a tool for safeguarding capital farmers' land. The patronage system that runs in the village is the driving force for the peasant's resistance in the Wonogoro area. The discussion process carried out by capital farmers in the mobilization process shows the intertwining of power relations that are formed in the patronage system. The actor besides having control through the land but on the other hand also shows the power relations through the knowledge of the peasants, with discussions and discourses that continue to be carried out by capital farmers. The peasant's resistance in the Wonogoro area is a strategy as a safety net for capital farmers in maintaining agricultural production capital. The strategy used by farmer actors is arguably strong enough in influencing proletarian farmers to join in rejecting social forestry. The strategy is used by actors seeing that there is a network that can be played as a way to continue to oppose and reject social forestry. mobilization carried out by the actors is quite strong because structurally the social forestry decree has been passed on to capital farmers in the Wonogoro area. Declaration letter for 2018 in October with number: SK.945 / MENLHKPSKL / PKPS / PSL.0 / 3/2018 with an arable area of 3,102 production plants. There is a social forestry certificate that has been issued but is ignored by most of the capital farmers who own large land, by holding discussions with NGOs.

The strategy of safe guarding land by capital farmers in peasants resistance in the Wonogoro area shows that the pattern of land protection is. The full mobilization of proletarian and full proletarian peasants in rejecting social forestry shows that class differentiation is very visible in social relations that occur in rural areas, especially in South Malang. Class differentiation causes peasants' resistance to stagnating and it can be said that resistance stagnation and loss of substance in peasants resistance. It is confusing that peasants' resistance to social forestry is considered a fake agrarian reform by peasants resistance actors. The dilemma of peasants' resistance was carried out by peasants in the Wonogoro area who were fighting for the existence of agrarian reform or land redistribution substantially.

The existence of a 2-hectare land redistribution scheme in social forestry is highly opposed by most of the capital farmers who become actors who are also capital farmers with large enough agricultural resources. Land security carried out by capital farmers with power through patronage legitimacy makes proletarian peasants. The control of proletarian peasants is not only as laborers but also as agricultural laborers in the process of securing land with mobilization carried out by capital farmers. The proletarian peasant's assumption that everything is done by the patron is a strategy to help proletarian peasants to make ends meet. Security of 
land through resistance to land redistribution from social forestry schemes. With this legitimacy, it is undeniable that the peasant's resistance in the Wonogoro area has not only lost direction in the spirit of the struggle of the peasants who want to realize agrarian reform but has instead created much greater inequality in the process of controlling exploited land. The agricultural production system, with working hours and wages, has led to greater class disparities in the Wonogoro area.

The peasant's resistance in rejecting the redistribution of 2 hectares of land is a form of discourse developed by NGOs with the assumption that there is a land redistribution of 2 hectares. The class conflict that occurs with redistribution must be paid handsomely by the capital farmers with the waning of land-based control and social status. The capital farmers mobilize the proletarian peasants against the peasant's resistance against social forestry and who will benefit the most in the Wonogoro peasant's resistance by rejecting land redistribution to proletarian peasants. The capital farmer has legitimacy capital and resource capital to be able to mobilize proletarian peasants to reject social forestry even though proletarian peasants also need this land.

\section{Class classification in peasant resistance}

A land tenure that occurs in the Wonogoro area shows how much land ownership is owned by most of the peasant's resistance actors/capital farmers. Land tenure can mobilize and mobilize proletarian peasants against social forestry even though social forestry certificates have been issued for capital farmers in the Wonogoro area. The dynamics of the farmer class formed in the peasant's resistance in the Wonogoro area in opposing social forestry show that the classification of the farmer class has a role in how much land is available. The tenure is owned by most of the actors who influence the resistance peasants. The resistance carried out by farmers in the Wonogoro area against social forestry is not necessarily without discourse production alone, but control can go hand in hand with resource ownership. The land resources are large enough so that the production patterns carried out by actors peasants resistance/capital farmers are based on land security in the process of redistribution of 2 hectares of land in a social forestry scheme. Land tenure has a major influence on the control of capital farmers in the Wonogoro area. The classification of the farmer class shows where the position of the capital farmer and the actor who benefits from the resistance of the peasants.

The class classification peasants' resistance in the Wonogoro area shows the role of the actor in fighting the Wonogoro area capital farmers with the amount of land they own. How big is the role of large landowners to be able to mobilize landless peasants and proletarian peasants? The resistance carried out by the peasants uses the classification into 5 categorizations of the peasant class in the capitalist rural areas with capitalist farmers, petty producer farmers, semi-proletarian farmers, proletarian and full proletarian farmers. The classification describes the amount of land or production capital owned by farmers so that it can influence proletarian farmers in their resistance to social forestry. The characteristics possessed by farmers in agricultural production show the number of patron lands so that they can mobilize capital farmers in the Wonogoro area.

The resistance carried out by capital farmers in rejecting social forestry is also inseparable from the relationship between capital farmers as actors in the market system. The banana commodity that develops in agriculture and markets in the Wonogoro area causes capital farmers to reject and mobilize proletarian peasants to reject social forestry. The social forestry scheme consists of dividing the amount of land and plants so that it greatly disturbs the banana production commodity that is developing in the Wonogoro area. The role of the peasant class is very influential in the pattern of mobilizing peasant resistance in the Wonogoro area. The relationship that develops in the production system is in the form of patronage so that the system makes it easier for capital farmers who have more land to control and mobilize proletarian peasants against social forestry.

The classification class social is formed inseparable from the existence of social relations between capital farmers and proletarian peasants in the Wonogoro area. Most of the capital farmers have an amount of land that is more than 3 hectares capable of catching the proletarian peasants. Ownership of more complete means of production such as spraying machines and owning land is not only a commodity, in this case, banana, but also coffee and cloves. The relationship with the 
proletarian peasants makes the capital farmer capable as the patron of the proletarian peasants who work in the agricultural production system.

The capital farmer has a safety net for proletarian peasants in the agricultural production system, such as providing basic assistance, both food and money, which the proletarian peasants pay with labor. Capital farmers who control a large area of land in the Wonogoro area do not sell themselves to the market of their production, besides having a large enough field, also some capital farmers are also middlemen and land tenants for proletarian peasants. The characteristics of capital farmers have a pattern of capital accumulation that they do and the use of labor used in agricultural production and the redistribution of commodity crops which are closely tied to the market system. Capital farmers accumulate production results by expanding production capital in the form of land.

Table 1. Semi Proletarian, Proletarian and Full Proletarian Class Production Work

\begin{tabular}{|l|l|c|c|}
\hline \multicolumn{1}{|c|}{ Class Farmers } & \multicolumn{1}{|c|}{ Type of Work } & $\begin{array}{c}\text { Working } \\
\text { Hours }\end{array}$ & \multicolumn{1}{c|}{ Labor Wages } \\
\hline \multirow{4}{*}{$\begin{array}{l}\text { Semi-proletarian } \\
\text { farmer }\end{array}$} & Make banana seeds & 11 hour & 50 thousand rupiahs/day \\
\cline { 2 - 4 } & $\begin{array}{l}\text { Clean the grass (jombret) and } \\
\text { old banana leaves }\end{array}$ & 11 hour & 50 thousand rupiahs/day \\
\cline { 2 - 4 } & Apply fertilizer & 11 hour & 75 thousand rupiahs/day \\
\cline { 2 - 4 } & $\begin{array}{l}\text { Harvest bananas and haul } \\
\text { roads }\end{array}$ & 11 hour & 50 thousand rupiahs/day \\
\hline \multirow{5}{*}{ Proletarian farmer } & Make banana seeds & 11 jam & 50 thousand rupiahs/day \\
\cline { 2 - 4 } & $\begin{array}{l}\text { Clean the grass (jombret) and } \\
\text { clean the old banana leaves }\end{array}$ & 11 hour & 50 thousand rupiahs/day \\
\cline { 2 - 4 } & Apply fertilizer & 11 hour & 75 thousand rupiahs/day \\
\cline { 2 - 4 } & $\begin{array}{l}\text { Harvest bananas and haul } \\
\text { roads }\end{array}$ & 11 hour & 50 thousand rupiahs/day \\
\hline \multirow{2}{*}{$\begin{array}{l}\text { Full } \\
\text { proletarian } \\
\text { farmer }\end{array}$} & Make banana seeds & 11 hour & 50 thousand rupiahs/day \\
\cline { 2 - 4 } & $\begin{array}{l}\text { Clean the grass (jombret) and } \\
\text { clean the old banana leaves }\end{array}$ & 11 hour & 50 thousand rupiahs/day \\
\cline { 2 - 4 } & Apply fertilizer & 11 hour & 75 thousand rupiahs/day \\
\cline { 2 - 4 } & Harvest banana & 11 hour & 50 thousand rupiahs/day \\
\hline
\end{tabular}

Source: Interview (2020)

Land control is a way of class classification for farmers in the Wonogoro area. The semi-proletarian and proletarian peasants are quite large in number compared to the capital farmers. In addition, there is a class that has no land or landlessness and these capital farmers only sell their labor to meet their subsistence needs. The proletarian farmers class in
Exploitation in agricultural systems with fairly strict working hours and short rest periods. The exploitation of daily labor wages for peasants labor varies from planting bananas to providing fertilizer with wages that vary from 50-75 thousand rupiah per day with working hours from 6 am to $4 \mathrm{pm}$ or some even until $5 \mathrm{pm}$. The classification class social in peasant resistance and the workload that most proletarian peasants have to bear. Capital farmers who have large enough land usually give a part of the land to be divided the results. The profit-sharing system is very burdensome for the majority of small farmers as expectant with $1 / 3$ and all production costs are all borne by the proletarian peasants as the workers of capital farmers only receive the results of agricultural production carried out by proletarian peasants. 
costs that must be incurred by proletarian farmers. The production costs are quite large and the rents are high enough to make proletarian farmers unable to carry out capital accumulation by owning their production land. Proletarian farmers are the inner class of farmers in the Wonogoro area, who are very pinched by the resistance of peasants in the Wonogoro area. The proletarian class can only live with the capital farmers.

\section{CONCLUSION}

Peasants resistance is the struggle of peasants who do not have arable land to fulfill subsistence. The resistance carried out by Wonogoro peasants shows that peasants' resistance is a paradox because it cannot be separated from access to control of land owned by capital farmers. Land control carried out by capital farmers is inseparable from the existence of land privatization that has been taking place since the beginning of land clearing. Massive privatization affects farmers' resistance when there is a social forestry policy with a 2-hectare land redistribution scheme that will threaten the production capital of capital farmers.

The differentiation of the peasant class that occurs in the Wonogoro area shows the position of the capital and proletarian farmer class in production relations. The capital farmer commands the production process and the proletarian farmer becomes a laborer to work on agricultural production to facilitate the control of capital farmers to proletarian peasants. In addition, land management has an impact on working hours and wages received by proletarian peasants. daily wages of 50 - 75 thousand rupiah with working hours of 11 hours per day. The exploitation process does not only stop at the agricultural production process but also proletarian farmers think that capital farmers are patrons because they are considered to provide safety nets both economically and socially, such as the billing system that runs there, they pay wages before doing work in the system, making the attachment easier. Peasants resistance has become a paradox because farmer protection actors are capital farmers who own more than 2 hectares of land.

The agricultural production process shows that the production results produced by most of the capital farmers in the Wonogoro area have accumulated by expanding cultivated land both in the Wonogoro area and outside. In addition, capital farmers are only used as a means of subsistence fulfillment. the use of production products cannot be separated from the social reproduction system.

The class dynamics that occur in the production process clearly show that the paradox of peasants 'resistance becomes real when there is a redistribution of land, the capital farmers in the name of the peasant's resistance reject social order. The interests of actors who become capital farmers are very clear that the initial resistance of peasants to defend the land for subsistence interests is transformed when the refusal of social care shows the interests of actors by mobilizing proletarian farmers who live from capital farmers.

\section{REFERENCES}

Adnan S. (2013). Land Grabs and Primitive Accumulation in Deltic Bangladesh: Interactions Between Neoliberal Globalization, State Interventions, Power Relations, and Peasant Resistance. The Journal of Peasant Studies. London (GB) 40(1), 87-128.

Ambarwati ME. (2018). Dynamics of Tenurial Conflict in State Forest Areas (Case in BKPH Responsibility for KPH Semarang). Bogor (ID): Jurnal Sodality.

Bartra R. (1993). Agrarian Structure and Political Power in Mexico. London (GB): The Johns Hopkins Univesity Pr.

Basole, A. and D. Basu. (2011). Relations of Production and Modes of Surplus Extraction in India: Part I - Agriculture. Economic \& Political Weekly, 46(14): 41-58.

Bernstein, H. (1986). Capitalism and Petty Commodity Production. In Rethinking Petty Commodity Production, AM Scott, ed. Special Issue series of Social Analysis, pp. 11-28.

Bernstein H. (1979). African Peasantries: A Theoretical Framework. London (GB). Journal of Peasant Studies.

Bernstein H. (1998). Social Change in the South African Counterside? Land and Production, Poverty and Power. London (GB) Journal of Peasant Studies.

Bernstein H. (2003). Farewells to The Peasantry. The African e Journal Project Michigan State University. Transformation 52. 
Bernstein H. (2010). Class Dynamics of Agrarian Change. London (GB). Halifax NS: Fernwood.

Borras MS. (2010). Gerakan-Gerakan Agraria Transnasional. Yogyakarta (ID): STPN Pr.

Bryant RL. (2008). Fighting Over the Forests: Political Reform, Peasant Resistance and The Transformation of Forest Management in Late Colonial Burma. London (UK): Journal of Common Wealt of Comparative Politics.

Creswell JW. (2015). Qualitative Research and Research Design: Choosing Between Five Approaches. Yogyakarta (ID): Pustaka Pelajar.

Daviron B, P Gibbon. (2002). Global Commodity Chains and African Export Agriculture. London (UK). Journal of Agrarian Change.

Denzin NK. (1978). The Research Act: A Theorical Introduction in Sociological Method. McGraw-Hills: New York (US): Routledge.

Gilmour D. (2016). Forty Year of Community Based Forestry. Rome (IT): FAO.

Habibi M. (2016). Labor Surplus in Peripheral Capitalism: Class Relations, Accumulation, and the Informal Proletariat in Indonesia Since the 1980s. Tangerang Selatan (ID): Marjin Kiri.

Habibi M. (2021). Master of Countryside and Their Enemie: Class Dynamics of Agrarian Change in Rural Java. London (UK): Journal of Agrarian Change.

Husken F. (1998). Village Community in Changing Times, History of Social Differentiation. Jakarta (ID): Grasindo.

Imadudin I. (2015). Peasants Resistance in the Private Land of Tanjoeng Oost Batavia in 1916. Bandung (ID): Patanjala, Vol 7.

Imaniar A, Brata NT. (2020). Client Patron Relationship between Middlemen and Salak Farmers with Social Impact in Banjarnegara. Semarang (ID): Solidarity.

KPA. (2019). End of Year Notes 2019 Consortium for Agrarian Reform From Aceh to Papua: The Urgency of Resolving Structural Conflicts and Ways of Agrarian Reform in the Future. Jakarta (ID): Konsorsium Pembaruan Agraria.

The East Java Coalition for Agrarian Care Demands to Stop Expansion of the Extraction Industry. (2014). Articles. Can be accessed by
Walhijatim.or.id/2017/04/koalisi-jatimpeduli-agraria-tuntut-hentikan-percepatanindustri-extractive/ accessed 23/03/18 at 05.30 WIB.

Kodir A, Adi AP. (2019). Peasant Resitance Movement towards BKPH (Bagian Kesatuan Pemangku Hutan- Forest Management Unit). Internasional Conference Rural Studies in Asian (Icorsia) 2018. Semarang (ID) Vol 313 HAL 1- 4.

KLHK. (2019). Indicative Map and Area of Social Forestry Revision III. Jakarta (ID): Kementrian Lingkungan Hidup dan Kehutanan.

Kuntowijoyo. (1993). Radicalization of Farmers: Historical Essays. Yogyakarta (ID): Main Intervention Range in Java 1830-1980. Jakarta (ID): Grasindo.

Luxemburg R. (2003). The Accumulation of Capital. London (GB): Routledge Classics

Mansur YH. (2014). Socio-Agrarian Conditions of Rice Fields in Sukabumi City. Bogor (ID): Jurnal Sodality.

Marx K. (1859). A Contribution to the Critique of Political Economy. Moscow (RU). Progress Publishers.

Mustain. (2007). Peasants vs State: Peasants Social Movements against State Hegemony. Yogyakarta (ID): Ar-Ruzz Media.

Moyo, S. (2007). Land in the Political Economy of African Development: Alternative Strategies for Reform. Harare (ZW). African Institute for Agrarian Studies. 32 (4), 1-34.

Paige JM. (2011). Agrarian Revolution Social Movement and Export Agriculture in The Developed Word. Yogyakarta (ID): Imperium Pr.

Patnaik U. (1976). Class Differentiation within the Peasantry: An Approach to Analysis of Indian Agriculture. New Delhi (IN): Economic and Political Weekly.

Popkin SL. (1979). The Rational Peasant: The Political Economiy of Rural Society in Vietnam. Berkeley (US): University of California Press.

Prause, L, Le billon, P. (2020). Struggles for land: comparing resistance movement against agro industrial and mining investment projects. 
London (UK): the Journal of Peasant Studies.

Rahmah DA, Soetarto E. (2014). The Movement of the Peasants' Association versus the State and Its Impact on the Welfare of the Sukamulya Village Community. Bogor (ID): Jurnal Sodality.

Ramidha M, Ahmadin, Jumadi. (2019). Client Patron Relations at the Marayoka Farmer Community in Jenepoto 1970-2018. Makasar (ID). Jurnal Pemikiran Pendidikan dan Penelitian Sejarah.

Sari L, Purwandari H. (2014). Changes in Agrarian Structure and Its Implications for the Rural Peasant Movement (Character Analysis Forum Paguyuban Petani Jasinga Pasca PPAN). Bogor (ID). Jurnal Sodality. Hal 1-4.

Scott J. (2007). Weapons of the Weak: Everyday Forms of Peasant Resistance. Yale (US). Yale university press.

Scott J. (1976). The Moral Economy of the Peasant: Rebellion and Subsistence in Southeast Asia. Yale (US): Yale university press

Soetarto E, Shohibudin M. (2005). Agrarian Reform: Main Prerequisites for Revitalizing Agriculture and Rural Areas. Jakarta (ID): Konsorsium Pembaruan Agraria.

Situmorang AW. (2013). Social Movements: Theory and Practice. Yogyakarta (ID): Pustaka Pelajar.

Sulistyo H. (2000). Sugarcane Sickle Hammer: A Forgotten History of Mass Massacre (19651960). Jakarta (ID): KPG.

Wiradi G. (2009). Agrarian Reform The Unfinished Journey. Bogor (ID): Sayogjo Institute.

Wolf ER. (1969). Peasant Wars of The Twentieth Century. New York (US): Harper, Row Publisher.

Worby, E. (2001). The New Agrarian Politics in Zimbabwe. London (UK). Journal of Agrarian Change.

Wulandari, Evy M, Ermy T. (2016). Analysis of the Patron-Client Relationship of former TCSDP UPP farmers in Koto Damai Village, Kiri Tengah District, Kampar Regency. Bogor (ID). Indonesia Journal Agricultural Economics. 